Tropical Journal of Pharmaceutical Research April 2019; 18 (4): 767-772

ISSN: $1596-5996$ (print); 1596-9827 (electronic)

(C) Pharmacotherapy Group, Faculty of Pharmacy, University of Benin, Benin City, 300001 Nigeria.

\title{
Effect of $n-3$ polyunsaturated fatty acids on dopaminergic neurons in substantia nigra, brain inflammatory response and behavior in mice with Parkinson's disease
}

\author{
Zhaowen Zhang ${ }^{1}$, Sisi Wang ${ }^{2,3}$, Chengyan $\mathrm{Li}^{1 \text { * }}$ \\ ${ }^{1}$ Department of Neurology, Renmin Hospital of Wuhan University, Wuhan 430060, ${ }^{2}$ Department of Neurology, the First College \\ of Clinical Medical Science, China Three Gorges University, ${ }^{3}$ Department of Neurology, Yichang Central People's Hospital, \\ Yichang 443003, Hubei Province, China
}

*For correspondence: Email: tf29518@163.com

Sent for review: 3 January 2019

Revised accepted: 29 March 2019

\begin{abstract}
Purpose: To examine the effect of $n-3$ polyunsaturated fatty acids (PUFAs) on dopaminergic neurons in substantia nigra, intracerebral inflammatory response and ethology in mice with Parkinson's disease $(P D)$.

Methods: Four groups of male C57BL/6 mice $(n=48)$ were used: normal control, negative control, $n$ 3PUFA, and Madopa groups. Except for normal control group, all groups were given 6hydroxydopamine hydrochloride (6-OHDA) to establish Parkinson's mice model. The expressions of tyrosine hydroxylase $(T H)$ and calcium-binding protein $(C B)$ in substantia nigra dopaminergic neurons were determined with immunohistochemistry and Western blot. The contents of nitric oxide (NO), tumor necrosis factor (TNF- $\alpha$ ) and interferon $y$ (IFN- $\gamma$ ) (indices of intracerebral inflammatory response) were measured. Tremor paralysis, moving grid number, standing times, swimming ability, and the number of rollers in each group were observed as indices of ethology.

Results: The number of TH and CB-positive neurons in the substantia nigra of n-3PUFA-treated mice was significantly increased, relative to those in Madopa-treated mice $(p<0.05)$. The expressions of TH and $C B$ proteins in substantia nigra in n-3PUFA group were markedly higher than the corresponding expressions in Madopa-treated mice $(p<0.05)$. Decreased levels of NO, TNF- $\alpha$ and IFN-y levels were seen in 3PUFA group, when compared to mice in Madopa group, but higher behavioral scores were obtained in $n$-3PUFA-treated mice, relative to Madopa-treated mice $(p<0.05)$.

Conclusion: The n-3PUFAs protect substantia nigra compact dopaminergic neurons against Parkinson's disease, alleviate immune inflammation, and improve the coordination of limb movement. Thus, $n$-3PUFAs have potential therapeutic application in the management of Parkinson's disease.
\end{abstract}

Keywords: Parkinson's disease, n-3 PUFAs, Substantia nigra, Dopaminergic neurons, Intra-cerebral inflammatory response

This is an Open Access article that uses a fund-ing model which does not charge readers or their institutions for access and distributed under the terms of the Creative Commons Attribution License (http://creativecommons.org/licenses/by/4.0) and the Budapest Open Access Initiative (http://www.budapestopenaccessinitiative.org/read), which permit unrestricted use, distribution, and reproduction in any medium, provided the original work is properly credited.

Tropical Journal of Pharmaceutical Research is indexed by Science Citation Index (SciSearch), Scopus, International Pharmaceutical Abstract, Chemical Abstracts, Embase, Index Copernicus, EBSCO, African Index Medicus, JournalSeek, Journal Citation Reports/Science Edition, Directory of Open Access Journals (DOAJ), African Journal Online, Bioline International, Open-J-Gate and Pharmacy Abstracts

\section{INTRODUCTION}

Parkinson's disease (PD) is a common neurodegenerative disease in the brain tissue outside the vertebral body. It is mainly due to necrosis of dopaminergic neurons in the substantia nigra and apoptosis, leading to the imbalance in dopamine-acetylcholine, which is 
characterized by a series of symptoms such as quiescent tremor, myotonia and postural disorders [1]. PD is a lifelong disease. Currently, the incidence of PD increases year by year, and there are no definite clinical measures for controlling and/or reversing the course of the disease. The main treatment strategy for PD patients is dopamine supplementation. However, exogenous dopamine preparations are associated with unwanted side effects, and the effectiveness of dopamine decreases or even fails with long-term administration. Consequently, there is need for research into more effective and low-toxicity drugs for clinical treatment of PD $[2,3]$.

The n-3 polyunsaturated fatty acids (n-3PUFAs) play important roles in protecting against neurodegenerative diseases associated with middle and old age. They comprise mainly of eicosapentaenoic acid (EPA) and docosahexaenoic acid (DHA). The latter accounts for $40 \%$ of the unsaturated fatty acids in the brain, and $50 \%$ of the plasma membrane of brain neurons. Studies have shown that $n-3$ PUFAs exert neuroprotective effects against Parkinson's disease, Alzheimer's disease and nerve injury [4]. The aim of this study was to investigate the protective effects of n-3PUFAs against substantia nigra dopaminergic neurons, intracerebral inflammatory response and behavioral characteristics in mice.

\section{EXPERIMENTAL}

\section{Laboratory animals and grouping}

Forty-eight clean grade C57BL/6 male mice weighing $20 \pm 2 \mathrm{~g}$ were allowed free access to feed and drinking water during I week of laboratory adaptation at a temperature of $19 \pm 3$ ${ }^{\circ} \mathrm{C}$ and humidity of $58 \pm 12 \%$. The mice were assigned without bias, to normal control, negative control, n-3PUFA, and Madopa groups, with 12 mice in each group. This research received approval from the Animal Ethical Committee of Department of Neurology, Renmin Hospital of Wuhan University, Wuhan 430060, Hubei Province, China (approval no. 201713249), and was carried out in line with the recommendations in "Principles of Laboratory Animal Care" (NIH publication no. 85-23, revised 1985) [5].

\section{Reagents and instruments}

The n-3PUFA preparations were purchased from Sigma-Aldrich Company (USA). Anhydrous ethanol was diluted and kept in a refrigerator at $80{ }^{\circ} \mathrm{C}$. Benzylhydrazide-levodopa (Madopa, with each tablet containing $200 \mathrm{mg}$ of L-dopa and $50 \mathrm{mg}$ of benzylenehydrazine hydrochloride), was provided by Shanghai Roche Pharmaceutical Co., Ltd. The sheep serum raw liquid for blocking, NO kit, TNF- $\alpha$ and IFN- $\gamma$ kit were provided by Beijing Zhongshan Biotechnology Co., Ltd. Mouse TH antibody, rabbit CaBP antibody, biotin binding goat anti-mouse monoclonal antibody and alkaline phosphatase binding goat anti-rabbit IgG were purchased from Sigma Company (USA).

\section{Establishment of PD mouse model}

Mice were administered 6-hydroxydopamine (6OHDA) to simulate PD. The mice in negative control group, n-3PUFA group and Madopa group were anesthetized by intraperitoneal injection of $10 \%$ chloral hydrate $(40 \mathrm{mg} / \mathrm{kg})$, and fixed on Stoelting stereotactic locator. Next, 20 $\mu \mathrm{g}$ of 6-OHDA was injected through the striatum of the skull with dental drill at the injection speed of $1 \mu \mathrm{L} / \mathrm{min} 1 \mathrm{~mm}$ behind the anterior fontanel, $3.0 \mathrm{~mm}$ to the left of the midline, and $5.0 \mathrm{~mm}$ below the dura mater. The needle was positioned for $10 \mathrm{~min}$, and then slowly withdrawn at the rate of $1 \mathrm{~mm} / \mathrm{min}$, after which the wound was sutured. The mice in the normal control group was fed but received no treatment. The negative control group was not treated after 6-OHDA administration for model preparation. Mice in the Madopa group were given the drug at a dose of $7.8 \mathrm{mg} / \mathrm{kg} /$ day through gavage, while mice in $\mathrm{n}-3$ PUFA group received $n-3$ PUFA via gavage at a dose of $2.0 \mathrm{~g} / \mathrm{kg} /$ day for 14 days. Mice behavior was observed throughout the experiment, and all mice were sacrificed after 14 days.

\section{Immunohistochemical, behavioral and biochemical assessments}

The average numbers dopaminergic neurons positive for $\mathrm{TH}$ and $\mathrm{CB} /$ unit area of substantia nigra were determined using immunohistochemical staining, while the expressions of $\mathrm{TH}$ and $\mathrm{CB}$ proteins were measured with western blot assay. The content of nitric oxide (NO) in brain homogenate was assayed spectrophotometrically, while TNF- $\alpha$ and IFN- $y$ were determined with enzyme linked immunosorbent assay (ELISA). All assays were carried out with assay kits in line with the manufacturers' protocol.

\section{Assessment of general behavior}

General behavior was assessed and scored for mice in each group [6]: absence of any symptoms was scored 0 ; free movement with intermittent tremor was scored 1 point; while 
gradual loss of activity, frequent tremors, and stiff hind limbs scored 2 points. Presence of limited movement, continuous tremor, stiff limbs, and frequent swallowing scored 3 points, while 4 points were given for general paralysis and death.

\section{Determination of number of autonomous activities}

The mice were placed for $10 \mathrm{~min}$ in a box with a square of dimensions $6 \mathrm{~cm} \times 6 \mathrm{~cm}$ at the bottom in a quiet dark environment. The number of times mice stood up, and moving lattices in 5 min were counted, and the average value was measured five times in succession.

\section{Swimming test}

Mice were placed in plexiglass water tank with water at a depth of $10 \mathrm{~cm}$ and water temperature of 22 to $25{ }^{\circ} \mathrm{C}$. The pattern of swimming in $1 \mathrm{~min}$ was recorded and scored. A score of 1 point was given for swimming with hind limbs and floating to one side occasionally; occasional swimming was scored 1.5 points; floating time accounting for more than half of the test time was scored 2.0 points; swimming most of the time, with occasional floatation was given 2.5 points; while 3.0 points were awarded for continuous swimming. The test was repeated 5 times at intervals of $1 \mathrm{~min}$, and the mean score was obtained.

\section{Roller test}

The ability of mice to maintain balance and continuous motion on a roller was tested. After adapting 5 times, the mean value for 5 tests carried out at 1-min intervals was obtained.

\section{Statistical analysis}

Numeric data are expressed as mean \pm standard deviation (SD), and were analyzed using Student's $t$-test. Other data are expressed as $n$ (\%), and comparison between groups was performed using $x^{2}$ test. All statistical analyses were carried out with SPSS19.0 software package. Statistical significance was fixed at $p<$ 0.05 .

\section{RESULTS}

\section{Changes in dopaminergic neurons in substantia nigra of mice}

Table 1 and Figure 1 to Figure 4 show that, relative to normal control mice, the numbers of $\mathrm{TH}$ - and $\mathrm{CB}-$ positive neurons in substantia nigra of the negative control were significantly decreased $(p<0.05)$. The neuronal distribution was zonal, the positive fibers and cells were sparse, and the area of the cell body decreased. In addition, the cytoplasm was lighter, and the neurites were thin and short. Moreover, marked differences were seen in the population of neurites and areas of cell bodies in $\mathrm{TH}$ - and CBpositive neurons.

Compared with Madopa group, the numbers of $\mathrm{TH}$ - and $\mathrm{CB}$-positive neurons in substantia nigra of n-3PUFAs group were significantly higher $(p<$ $0.05)$. Moreover, the neurons were distributed in clusters, positive fibers and cells were intensive, cell body area was larger, the cytoplasm was darker, and neurites were thicker and longer. The cell body area and number, and length and number of neurites were markedly increased $(p<$ 0.05). The expressions of $\mathrm{TH}$ protein and CB protein in substantia nigra of n-3PUFAs group were markedly upregulated, relative to the Madopa-treated mice $(p<0.05)$.

Table 1: Number of positive cells and protein expression in substantia nigra (mean $\pm S D, n=12$ )

\begin{tabular}{|c|c|c|c|c|}
\hline \multirow[t]{2}{*}{ Group } & \multicolumn{2}{|c|}{$\begin{array}{l}\text { Number of } \\
\text { positive cells in } \\
\text { substantia nigra }\end{array}$} & \multicolumn{2}{|c|}{$\begin{array}{l}\text { TH and CB } \\
\text { protein } \\
\text { expression in } \\
\text { substantia } \\
\text { niqra }\end{array}$} \\
\hline & $\mathrm{TH}^{+}$ & $\mathrm{CB}^{+}$ & $T H$ & $C B$ \\
\hline Normal & $\begin{array}{l}57.54 \pm \\
10.74\end{array}$ & $\begin{array}{l}36.42 \pm \\
6.65\end{array}$ & $\begin{array}{l}1.24 \pm \\
0.23\end{array}$ & $\begin{array}{l}1.15 \pm \\
0.19\end{array}$ \\
\hline $\begin{array}{l}\text { Negative } \\
\text { control }\end{array}$ & $\begin{array}{l}34.86 \pm \\
8.63^{*}\end{array}$ & $\begin{array}{l}19.74 \pm \\
5.83^{\star}\end{array}$ & $\begin{array}{l}1.00 \pm \\
0.00^{*}\end{array}$ & $\begin{array}{l}1.00 \pm \\
0.00^{*}\end{array}$ \\
\hline N-3PUFAs & $\begin{array}{l}63.75 \pm \\
12.49^{\#}\end{array}$ & $\begin{array}{l}56.48 \pm \\
7.52^{\#}\end{array}$ & $\begin{array}{l}1.97 \pm \\
0.57^{\#}\end{array}$ & $\begin{array}{l}1.88 \pm \\
0.77^{\#}\end{array}$ \\
\hline Madopa & $\begin{array}{l}30.53 \pm \\
5.31\end{array}$ & $\begin{array}{l}21.27 \pm \\
6.15\end{array}$ & $\begin{array}{l}1.00 \pm \\
0.00\end{array}$ & $\begin{array}{l}1.00 \pm \\
0.00\end{array}$ \\
\hline
\end{tabular}

${ }^{\star} P<0.05$ ), relative to normal mice, $\# p<0.05$, relative to madopa-treated mice

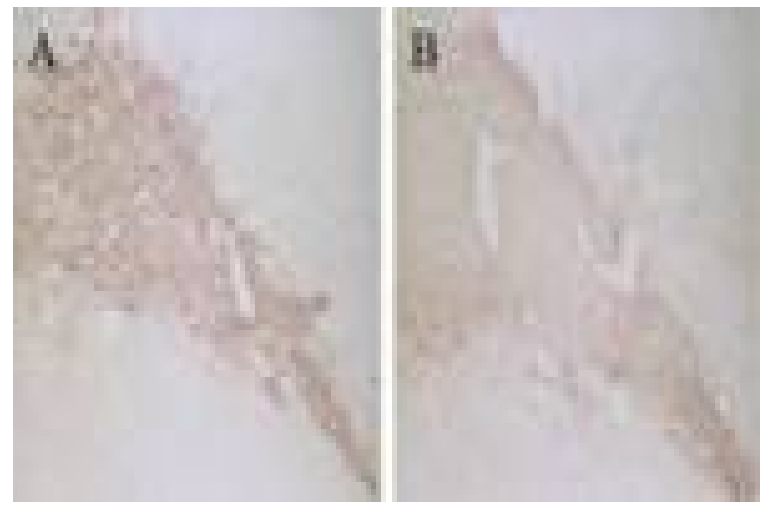

Figure 1: Immunohistochemical staining of $\mathrm{TH}$. A: Immunohistochemical staining of $\mathrm{TH}$ in normal control group. B: Immunohistochemical staining of $\mathrm{TH}$ in negative control group 


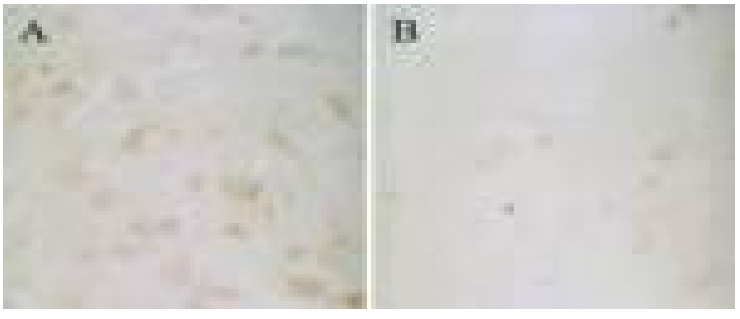

Figure 2: Immunohistochemical staining of CB. A: Immunohistochemical staining of $\mathrm{CB}$ in normal control group; $B$ : Immunohistochemical staining of $\mathrm{CB}$ in negative control group

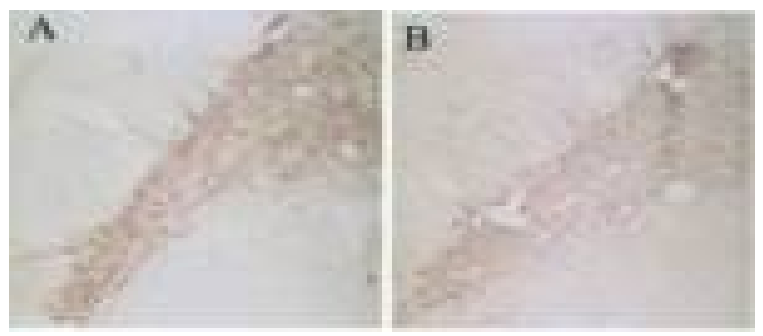

Figure 3: Immunohistochemical staining of $\mathrm{TH}$. A: Immunohistochemical staining of $\mathrm{TH}$ in $\mathrm{n}$-3PUFAs group; B: Immunohistochemical staining of $\mathrm{TH}$ in madopa group

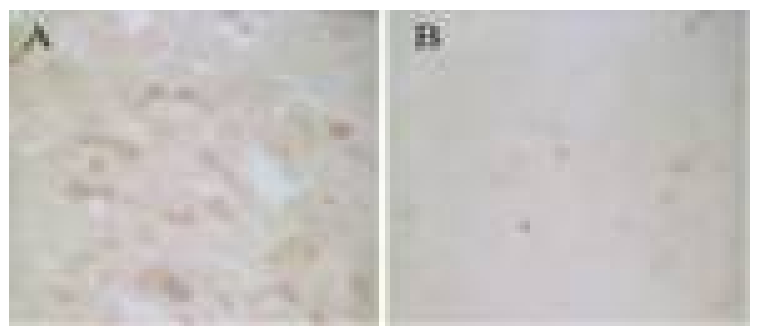

Figure 4: Immunohistochemical staining of CB. A: Immunohistochemical staining of $C B$ in $n$-3PUFAs group; B: Immunohistochemical staining of $\mathrm{CB}$ in madopa group

\section{Inflammatory factors in mouse brain}

The contents of NO, TNF- $\alpha$ and IFN-y in the brain homogenate of the negative control group were significantly higher than those in the normal control group, n-3PUFAs group and Madopa group $(p<0.05)$. The NO, TNF- $\alpha$ and IFN- $y$ levels in the n-3PUFAs group were significantly lower than those in the Madopa group $(p<0.05)$.
There were no marked differences in these parameters between n-3PUFAs group and normal control group $(p>0.05)$. These results are shown in Table 2.

\section{Behavioral score}

Table 3 shows that acute reactions such as hair raising, arching of dorsal region, decreased movement, limb tremor and gait instability occurred in mice 3 - 5 min after establishment of the PD model. These behavioral changes in mice were obvious within $1 \mathrm{~h}$ and returned to normal after $24 \mathrm{~h}$. Lower behavioral scores were recorded in the negative control mice, when compared to normal control mice $(p<0.05)$. Behavioral scores in n-3PUFA mice were markedly superior to those in Madopa-treated mice $(p<0.05)$.

Table 2: NO, TNF- $\alpha$ and IFN- $\gamma$ levels in brain homogenate (mean $\pm S D, n=12$ )

\begin{tabular}{lccc}
\hline Group & $\begin{array}{l}\text { NO } \\
(\boldsymbol{\mu m o l} / \mathbf{g})\end{array}$ & $\begin{array}{c}\text { TNF- } \alpha \\
(\mathbf{n g} / \mathbf{L})\end{array}$ & $\begin{array}{l}\text { IFN-y } \\
(\mathbf{n g} / \mathbf{L})\end{array}$ \\
\hline Normal & $3.27 \pm$ & $0.16 \pm$ & $0.42 \pm$ \\
control & 0.66 & 0.05 & 0.10 \\
Negative & $5.93 \pm$ & $0.36 \pm$ & $0.83 \pm$ \\
control & $0.79^{*}$ & $0.12^{*}$ & $0.25^{*}$ \\
N-3PUFAs & $3.51 \pm$ & $0.21 \pm$ & $0.47 \pm$ \\
& $0.86^{\#}$ & $0.13^{\#}$ & $0.17^{\#}$ \\
Madopa & $4.25 \pm$ & $0.33 \pm$ & $0.65 \pm$ \\
& 0.58 & 0.11 & 0.20 \\
\hline$\left.{ }^{*} P<0.05\right)$, & relative to normal control; $\# p<0.05$
\end{tabular}

relative to Madopa-treated mice

\section{DISCUSSION}

Parkinson's disease (PD) is a chronic degenerative disease of extra-vertebral system which has not been completely understood. It may be related to heredity, environmental factors, oxidative stress, and immunoinflammatory responses [7]. Several reports indicate that neuro-degeneration, necrosis of dopaminergic neurons in the polynigral striatum; glial cell proliferation and formation of Louie's corpuscles are directly related to the pathogenesis of PD [8].

Table 3: Behavioral score (mean $\pm \mathrm{SD}, \mathrm{n}=12$ )

\begin{tabular}{lccccc}
\hline \multirow{2}{*}{ Group } & \multicolumn{5}{c}{ Behavior data } \\
\cline { 2 - 6 } & $\begin{array}{c}\text { Tremor paralysis } \\
\text { score }\end{array}$ & $\begin{array}{c}\text { Standing } \\
\text { times }\end{array}$ & $\begin{array}{c}\text { Moving grid } \\
\text { times }\end{array}$ & Swimming test & Roller test \\
\hline Normal control & $0.00 \pm 0.00$ & $24.62 \pm 7.86$ & $73.54 \pm 7.71$ & $2.95 \pm 1.41$ & $22.65 \pm 5.71$ \\
Negative control & $2.23 \pm 1.25^{\star}$ & $15.53 \pm 5.48^{\star}$ & $53.25 \pm 6.33^{\star}$ & $1.52 \pm 0.58^{\star}$ & $11.50 \pm 4.32^{\star}$ \\
N-3PUFAs & $2.22 \pm 1.26^{\#}$ & $20.73 \pm 7.69^{\#}$ & $67.83 \pm 9.32^{\#}$ & $16.52 \pm 4.63^{\#}$ & $2.43 \pm 1.16^{\#}$ \\
Madopa & $1.63 \pm 0.95$ & $14.82 \pm 6.13$ & $52.83 \pm 9.32$ & $12.73 \pm 3.88$ & $1.67 \pm 0.64$ \\
\hline
\end{tabular}

${ }^{\star} P<0.05$ ), relative to normal control mice; $\# p<0.05$, relative to madopa-treated mice 
A large number of studies have shown that $n$ 3PUFAs have many physiological functions such as protection from cardiovascular disease, as well as anti-inflammatory, antioxidant and antiapoptosis properties. Some scholars believe that n-3PUFAs protect the central nervous system through their anti-inflammatory effects [9]. The present study was carried out to investigate the protective effect of n-3PUFAs in a pathological model of PD, and to see if they exert antagonizing effects on 6-OHDA-induced inflammatory responses, thereby improving motor dysfunction in PD mice.

Autonomic activity count, swimming test and roller test are standard procedures for assessing the behavior of PD mice, since they accurately reflect relative behavioral changes such as decrease in movement, retardation and coordination [10].

Tyrosine hydroxylase (TH) exists mainly in substantia nigra dopaminergic neurons. It is a key enzyme in DA synthesis and a marker of DA neurons. The $\mathrm{CB}$ of normal mice is mainly expressed in the substantia nigra in the compact part and ventral tegmental area. The DA neurons containing $\mathrm{CB}$ have anti-denaturation effect which can prevent the toxic effect of calcium overload by combining with intracellular calcium ions, thus exerting the cytoprotective effect [11].

The results obtained in this study showed that the behavioral changes in PD mice model were closely related to changes in morphology and expressions of $\mathrm{TH}$ and $\mathrm{CB}$ neurons before and after the treatments. The behavioral scores in $\mathrm{n}$ 3PUFA-treated mice were markedly higher than those in Madopa-treated mice. The number and protein expressions of $\mathrm{TH}$ - and CB-positive neurons in substantia nigra in n-3PUFAs group were markedly higher than those in Madopatreated mice group, which suggests that n3PUFAs improved the behavioral disorders in the PD mice model. This improvement was effected by promoting the expressions of $\mathrm{TH}$ and $\mathrm{CB}$, promoting axon growth and differentiation, and enhancing the plasticity and self-protection of dopaminergic neurons. The results of this study are consistent with those of reported by Wang et al [12].

Nitric oxide (NO) is a small molecule with a wide range of biological effects. It is normally in a state of sustained dynamic equilibrium in tissues while playing its biological messenger role. It damages membrane structure and function by acting on cytomembrane and mitochondrial membrane, and induces nerve cell death [13]. In addition, NO causes nerve cell damage by activating the energy dissipation reaction of ADPribonucleosynthesis (PARS). Moreover, NO itself has free radical cytotoxicity which also leads to cell injury. Thus, NO can participate in DA nerve injury through several ways.

In the central nervous system, TNF- $\alpha$ and IFN- $\gamma$ are secreted mainly by astrocytes and microglia. As a pro-inflammatory factor, TNF- $\alpha$ induces and promotes inflammation, cytotoxicity and other reactions involved in activation of the apoptosis pathway, thereby aggravating cell injury. In contrast, IFN- $y$ activates microglia and induces the up-regulation of MHC-II on the cell surface, which results in more NO production and further aggravation of neuronal injury $[14,15]$. The findings in the current study showed that the contents of NO, TNF- $\alpha$ and IFN- $\gamma$ in n-3PUFAs group were appreciably lower than those in Madopa-treated mice. This indicates that $\mathrm{n}$ 3PUFAs decrease the contents of NO, TNF- $\alpha$ and IFN-y in brain cells, and reduce immune inflammation and related toxic substances associated with PD. The related mechanism may be that EPA and DHA inhibit the expressions of NF-kB and other inflammatory factors induced by lipopolysaccharide, and decrease the phosphorylation of I-kB subunit [16].

\section{CONCLUSION}

These results suggest that $n$-3PUFAs mitigate the motor disorders associated with PD in a 6OHDA-induced mice model of the disease, and protect DA neurons by increasing the expression of $\mathrm{CB}$ in the cells. In addition, they reduce inflammatory responses via down regulation of inflammatory mediators. Thus, n-3PUFAs have a potential therapeutic effect on Parkinson's disease.

\section{DECLARATIONS}

\section{Conflict of Interest}

No conflict of interest associated with this work.

\section{Contribution of Authors}

We declare that this work was done by the author(s) named in this article and all liabilities pertaining to claims relating to the content of this article will be borne by the authors. All authors read and approved the manuscript for publication. Chengyan $\mathrm{Li}$ conceived and designed the study, Zhaowen Zhang, Sisi Wang, Chengyan Li collected and analyzed the data. Zhaowen Zhang wrote the manuscript. 


\section{Open Access}

This is an Open Access article that uses a funding model which does not charge readers or their institutions for access and distributed under the terms of the Creative Commons Attribution License (http://creativecommons.org/licenses/by/ 4.0) and the Budapest Open Access Initiative (http://www.budapestopenaccessinitiative.org/rea d), which permit unrestricted use, distribution, and reproduction in any medium, provided the original work is properly credited.

\section{REFERENCES}

1. Sampson TR, Debelius JW, Thron T, Janssen S, Shastri GG, Ilhan ZE, Challis C, Schretter CE, Rocha S, Gradinaru $V$, et al. Gut Microbiota Regulate Motor Deficits and Neuroinflammation in a Model of Parkinson's Disease. Cell 2016; 167(6): 1469-1480.

2. Schrag A, Jahanshahi M, Quinn N. How does Parkinson's disease affect quality of life? A comparison with quality of life in the general population. Mov Disord 2015; 15(6): 1112-1118.

3. Liu J, Duan CL, Yang H. Research Progress of Pathogenesis and Treatment of Parkinson's Disease. Progress Physiol Sci 2015; 46(3): 163-169.

4. Fang $X$, Ge $K$, Song $C$, Ge $Y$, Zhang J. Effects of $n$ 3PUFAs on autophagy and inflammation of hypothalamus and body weight in mice. Biochem Biophys Res Commun 2018; 501(4): 927-932.

5. World Health Organization. Principles of laboratory animal care. WHO Chron 1985; 39: 51-56.

6. SUN ZH, XU YX, Guo K. Gender difference in pain behavior of rats with 6-OHDA induced Parkinson's disease. Chin J Pain Med 2017; 23(11): 811-817.

7. Chaudhuri KR, Healy DG, Schapira AH. Non-motor symptoms of Parkinson's disease: diagnosis and management. Lancet Neurol 2017; 5(3): 235-245.
8. Pierson J, Norris JL, Aerni HR, Svenningsson P, Caprioli RM, Andrén PE. Molecular profiling of experimental Parkinson's disease: direct analysis of peptides and proteins on brain tissue sections by MALDI mass spectrometry. J Proteome Res 2015; 3(2): 289-295.

9. Li M, Ouyang $H$, Yuan H, Li J, Xie Z, Wang K, Yu T, Liu $M$, Chen $X$, Tang $X$, et al. Site-Specific Fat-1 Knock-In Enables Significant Decrease of $n$-6PUFAs/n-3PUFAs Ratio in Pigs. G3 (Bethesda) 2018; 8(5): 1747-1754.

10. Zhou J, Bao LW, Liang J. Behavior improvement and inflammatory regulation in Parkinson's disease rats after neural stem cell transplantation. Chin J Tissue Eng Res 2017; 21(33): 5299-5304.

11. Cao L, Li D, Feng P, Li L, Xue GF, Li G, Hölscher C. A novel dual GLP-1 and GIP incretin receptor agonist is neuroprotective in a mouse model of Parkinson's disease by reducing chronic inflammation in the brain. NeuroReport 2016; 27(6): 384-391.

12. Wang $Y Q$, Liu HM, Xiao CH, Gao DS. Effects of lithium chloride on expression of calbindin-D28k of MPTPinduced Parkinsons disease mice. J Brain Nervous Dis 2016; 24(10): 650-653.

13. Xu PY, Qu SG, Yang XL, Li SM, Mo MS, Xiao YS, Cen L, Chen $X$. Inflammation, immune mechanism and related markers of Parkinson's Disease. J Diagn Concepts LPract 2016; 2: 96-101.

14. Wang $Q$, Liu $Y$, Zhou J. Neuroinflammation in Parkinson's disease and its potential as therapeutic target. Trans/ Neurodegener 2015; 4(1): 19.

15. Shi P, Qu H D, Li Q, Chen YH, Li QQ, Xie J. The serum levels of activated $T$ cells chemokines Rantes and inflammatory cytokines in Parkinson's disease patients and its significance. J Bengbu Med College 2016; 41(9): 1132-1135.

16. Thomazeau A, Boschbouju C, Manzoni O, Layé $S$. Nutritional $n-3$ PUFA Deficiency Abolishes Endocannabinoid Gating of Hippocampal Long-Term Potentiation. Cereb Cortex 2017; 27(4): 2571-2579. 